\title{
Acute intermittent porphyria caused by novel mutation in HMBS gene, misdiagnosed as cholecystitis
}

This article was published in the following Dove Press journal:

Neuropsychiatric Disease and Treatment

I2 November 2014

Number of times this article has been viewed

\author{
Majid Alfadhel ${ }^{1,3}$ \\ Neam Saleh ${ }^{2}$ \\ Helal Alenazi ${ }^{2}$ \\ Henry Baffoe-Bonnie ${ }^{2}$ \\ 'Division of Genetics, Department \\ of Pediatrics, ${ }^{2}$ Division of General \\ Medicine, Department of Medicine, \\ King Abdulaziz Medical City, Riyadh, \\ Kingdom of Saudi Arabia; ${ }^{3}$ College \\ of Medicine, King Saud Bin Abdulaziz \\ University for Health Sciences, Riyadh, \\ Kingdom of Saudi Arabia
}

Background: Acute intermittent porphyria (AIP) is an autosomal dominant neurovisceral inherited disorder due to a defect in the heme biosynthesis pathway. Misdiagnosis of the porphyrias is not uncommon.

Case report: We present a case of a 26-year-old female with suspected acute cholecystitis, mental status changes, and seizures. Biochemical and molecular investigations confirmed the diagnosis of AIP by findings of elevated urinary porphobilinogen, 5-aminolevulinic acid, and total porphyrins. DNA molecular testing showed a novel heterozygous mutation (c. 760delC p.L254X) in the exon11 of the HMBS gene. To the best of our knowledge, this is the first report of a misdiagnosis of AIP presenting with acute cholecystitis.

Conclusion: Clinicians are alerted to consider the possibility of AIP in an adult presenting with an acute abdomen, features of cholecystitis, and neuropsychiatric manifestations.

Keywords: porphyria, cholecystitis, acute abdomen, acute intermittent porphyria, HMBS gene, hydroxymethylbilane synthase

\section{Introduction}

Acute intermittent porphyria (AIP) (MIM\#176000) is an autosomal dominant inborn disorder of heme biosynthesis, that is cause by a mutation in the gene encoding hydroxymethylbilane synthase $(H M B S)$ or porphobilinogen deaminase. ${ }^{1}$ Currently, $>386$ mutations are known in $H M B S$ gene, mostly, missense, nonsense, splicing site mutations, deletions, insertions, or duplications. ${ }^{2}$ Because AIP is rare and its clinical presentation is heterogeneous, it can be easily misdiagnosed. However, a diagnosis of AIP masquerading as acute cholecystitis has not been reported yet in the literature. We describe a 26-year-old woman with AIP, misdiagnosed initially as cholecystitis and found to have a novel heterozygous mutation in the $H M B S$ gene.

\section{Case report}

The Saudi female patient in the UK developed recurrent bouts of abdominal pain, nausea, and vomiting during first pregnancy, diagnosed as hyperemesis gravidarum, and was treated with IV fluids and antiemetics. There was improvement in the condition and the patient delivered a healthy child (in Saudi). After 2 months, the patient presented with a bout of severe abdominal pain (diagnosed as cholecystitis), followed by repeated seizures, hyponatremia, elevated and uncontrolled blood pressure, sinus tachycardia, delirium, lower limb weakness, hyporeflexia, and psychological abnormalities. She was intubated for 3 days. Initial postextubation, physical examination 
result was unremarkable except for unexplained behavioral disturbances and lower limb weakness. Initial instigations showed sodium levels ranged between 118-125 mmol/L (135-144 mmol/L), mildly elevated transaminases (aspartate aminotransferase [AST]/alanine transaminase [ALT]), and slight elevation of anti-neutrophil antibodies of the perinuclear type (P-ANCA). Alkaline phosphatase, bilirubin, complete blood count (CBC), thyroid-stimulating hormone (TSH), vitamin B12 level - markers for connective tissue diseases, viral titer values, and cerebrospinal fluid (CSF) analysis findings were all within normal range. The abdominal imaging result was normal, except for contracted gallbladder and stones.

Urine became dark red on exposure to light. Total porphyrins in urine were elevated: $29,100 \mathrm{nmol} / 24$ hours (normal: $\leq 214$ ), with main elevation in uroporphyrin level, 24,200 nmol/24 hours (normal: $\leq 30$ ), and mild elevation in coproporphyrin level, $118 \mathrm{nmol} / 24$ hours (normal: $\leq 38$ ). DNA molecular testing showed a novel heterozygous mutation in the exon 11 of the $H M B S$ gene (c. 760delC p.L254X). The patient was treated with intravenous heme arginate ( $4 \mathrm{mg} / \mathrm{kg} /$ day) for 5 days, that was followed by an improvement in the chemical and clinical parameters.

\section{Discussion}

AIP manifests later in life; only $10 \%$ to $15 \%$ of those exhibiting carrier types develop the clinical syndrome. ${ }^{3}$ Typically, patients suffer intermittent bouts of neurovisceral attacks for up to several days, recurring over several weeks, manifesting as severe abdominal pain ( $>95 \%$ of cases) and neurological and/or psychological symptoms. Abdominal pain is associated with nausea, vomiting, and constipation. Psychological symptoms vary, including mood swings, depression, anxiety, and occasionally, auditory and visual hallucinations, disorientation, and mental deterioration. Neurological features can affect the central/peripheral nervous system, leading in some cases to seizure, severe myalgia, ascending flaccid paralysis and in catastrophic cases to respiratory arrest or irreversible quadriplegia. Other commonly encountered findings include difficult to treat hypertension, tachycardia and SIADH induced hyponatremia. External triggers may be porphyrinogenic drugs, alcohol, infections, calorie-restricted diet, and stress; internal triggers are hormonal (pregnancy and menstrual cycle). ${ }^{2}$

Diagnosis of AIP is biochemical/molecular dependent. Biochemical testing, usually, shows increased concentrations of porphobilinogen, 5-aminolevulinic acid, and total porphyrins in the urine (mainly uroporphyrins), with decreased enzyme activity of porphobilinogen deaminase $(\leq 50 \%)$ in erythrocytes. Fecal porphyrin levels are normal or increased. Diagnosis of AIP is confirmed by the detection of heterozygous mutation in the $H M B S$ gene. ${ }^{4}$ In the presented case, the pathogenicity of this novel mutation is supported by creation of premature stop codon, which is very likely to result in truncated protein or loss of protein production.

AIP can be misdiagnosed as psychosis, Guillain-Barré syndrome, and chronic hepatitis (Table 1). ${ }^{5-7}$ The presented patient was misdiagnosed as having cholecystitis, as she presented with severe abdominal pain and gallbladder stones; however, the neuropsychiatric manifestations made the treating physicians rethink about the diagnosis and treatment. To avoid such misdiagnosis in the future, the clinicians should consider the possibility of AIP in any individual presenting with an acute abdomen and neuropsychiatric manifestations.

Attacks of AIP are typically triggered by stress; symptoms start during pregnancy. Perhaps, supportive care obfuscated manifestations of porphyric attacks. Nonetheless, increased estrogen and progesterone levels in pregnancy may precipitate

Table I Misdiagnosis of acute intermittent porphyria

\begin{tabular}{|c|c|c|}
\hline Authors & Misdiagnosis & Summary of the case \\
\hline Ohtani et al" & Hepatitis & $\begin{array}{l}\text { 44-year-old female with abdominal pain } \\
\text { and found to have high transaminases } \\
>1,000 \mathrm{mU} / \mathrm{mL}\end{array}$ \\
\hline Kumar $^{5}$ & Psychosis & $\begin{array}{l}\text { I5-year-old female diagnosed with } \\
\text { schizophrenia I year ago presented to the } \\
\text { psychiatric hospital with bizarre behavior of } \\
2 \text { days' duration }\end{array}$ \\
\hline Cuquemelle et $\mathrm{a}^{6}$ & Guillain-Barré syndrome & $\begin{array}{l}26 \text {-year-old female hospitalized in } \\
\text { intensive care unit for acute respiratory } \\
\text { failure associated with an acute } \\
\text { polyradiculoneuropathy }\end{array}$ \\
\hline
\end{tabular}


porphyric attacks. The currently recommended and effective treatments in the moderate to severe cases, are the early administration of IV human hemin along with glucose loading, discontinuation of triggering porphinogenic drugs, and symptomatic treatments of the concomitant hypertension, tachycardia, pain and neurological symptoms.

The cause of neuropsychiatric manifestations in AIP is not well understood. Several investigators suggested that increased levels of hepatic 5-aminolevulinic acid and porphobilinogen may play an essential role in the occurrence of such complications, and the supportive evidence of such theory is the finding that several patients with severe AIP became asymptomatic after liver transplantation. ${ }^{8}$ Other postulated mechanisms include focal demyelination, vacuolization of the neurons, and multifocal ischemia resulting from a vascular narrowing and/or glial proliferation. ${ }^{9}$ Treatment of such complications consists of prompt intervention with the aforementioned supportive measures; in addition, gabapentin proves its effectiveness in reducing neuropathic pain and seizure episodes. ${ }^{10}$

\section{Conclusion}

AIP could be misdiagnosed as cholecystitis. Our report adds a novel nonsense mutation to the previously reported AIP mutations.

\section{Disclosure}

The authors report no conflicts of interest in this work.

\section{References}

1. Llewellyn DH, Scobie GA, Urquhart AJ, et al. Acute intermittent porphyria caused by defective splicing of porphobilinogen deaminase RNA: a synonymous codon mutation at $-22 \mathrm{bp}$ from the $5^{\prime}$ splice site causes skipping of exon 3. J Med Genet. 1996;33(5):437-438.

2. Whatley SD, Badminton MN. Acute Intermittent Porphyria. In: Pagon RA, Adam MP, Ardinger HH, Bird TD, Dolan CR, Fong CT, Smith RJH, Stephens K, editors. Source GeneReviews ${ }^{\circledR}$ [Internet]. Seattle (WA): University of Washington; 1993-2014.

3. Farfaras A, Zagouri F, Zografos G, Kostopoulou A, Sergentanis TN, Antoniou S. Acute intermittent porphyria in pregnancy: a common misdiagnosis. Clin Exp Obstet Gynecol. 2010;37(4):256-260.

4. Anderson KE, Bloomer JR, Bonkovsky HL, et al. Recommendations for the diagnosis and treatment of the acute porphyrias. Ann Intern Med. 2005;142(6):439-450.

5. Kumar B. Acute intermittent porphyria presenting solely with psychosis: a case report and discussion. Psychosomatics. 2012;53(5):494-498.

6. Cuquemelle E, Ehrmann S, Razazi K, Deybach JC, Brun-Buisson C, Thille AW. An atypical case of Guillain-Barré syndrome: acute intermittent porphyria. Intensive Care Med. 2012;38(5):913-914.

7. Perez Martinez J, Castro Marquez C, Pereira Gallardo S, Jimenez Saenz M, Herrerias Gutierrez JM. Porfiria aguda intermitente subclínica. Etiología inusual de hepatitis crónica [Subclinical acute intermittent porphyria. An uncommon cause of chronic hepatitis]. Gastroenterol Hepatol. 2011; 34(4):262-265. Spanish.

8. Soonawalla ZF, Orug T, Badminton MN, et al. Liver transplantation as a cure for acute intermittent porphyria. Lancet. 2004; 363(9410):705-706.

9. Maramattom BV, Zaldivar RA, Glynn SM, Eggers SD, Wijdicks EF. Acute intermittent porphyria presenting as a diffuse encephalopathy. Ann Neurol. 2005;57(4):581-584.

10. Lin TC, Lai SL, Hsu SP, Ro LS. Treatment of neuropathic pain in acute intermittent porphyria with gabapentin. JFormos Med Assoc. 2013;112(9): 578-579.

11. Ohtani Y, Yamaoka M, Sawada M, Miyazaki Y, Miyazaki R, Okayasu I, et al. Acute intermittent porphyria associated with transient elevation of transaminases during an acute attack. Intern Med. 2000;39(1):45-49.
Neuropsychiatric Disease and Treatment

\section{Publish your work in this journal}

Neuropsychiatric Disease and Treatment is an international, peerreviewed journal of clinical therapeutics and pharmacology focusing on concise rapid reporting of clinical or pre-clinical studies on a range of neuropsychiatric and neurological disorders. This journal is indexed on PubMed Central, the 'PsycINFO' database and CAS,

\section{Dovepress}

and is the official journal of The International Neuropsychiatric Association (INA). The manuscript management system is completely online and includes a very quick and fair peer-review system, which is all easy to use. Visit http://www.dovepress.com/testimonials.php to read real quotes from published authors. 